\title{
Chemical composition and antimicrobial activity of essential oils of Ocimum canum Sims. and Ocimum selloi Benth.
}

\author{
JEFERSON C. NASCIMENTO ${ }^{1}$, LUIZ C.A. BARBOSA ${ }^{2}$, VANDERLUCIA F. PAULA ${ }^{1}$, \\ JORGE M. DAVID ${ }^{3}$, RENATO FONTANA ${ }^{4}$, LUIZ A.M. SILVA ${ }^{4}$ and ROBSON S. FRANÇA ${ }^{1}$ \\ ${ }^{1}$ Departamento de Química e Exatas, Universidade Estadual do Sudoeste da Bahia, UESB, \\ Rua José Moreira Sobrinho s/n, 45206-190 Jequié, BA, Brasil \\ ${ }^{2}$ Departamento de Química, Universidade Federal de Viçosa, UFV, \\ Avenida Peter Henry Holfs s/n, 36571-000 Viçosa, MG, Brasil \\ ${ }^{3}$ Instituto de Química, Universidade Federal da Bahia, UFBA, \\ Rua Barão de Geremoabo s/n, 40170-290 Salvador, BA, Brasil \\ ${ }^{4}$ Departamento de Ciências Biológicas, Universidade Estadual de Santa Cruz, UESC, \\ Km 16 Rodovia Ilhéus-Itabuna 45662-000 Ilhéus, BA, Brasil
}

Manuscript received on December 9, 2009; accepted for publication on January 1, 2011

\begin{abstract}
This work describes the chemical composition and antimicrobial activity of the volatile oils of Ocimum canum and Ocimum selloi, both occurring in Jequié/BA, northeastern Brazil. The plants were collected in the winter/2005 and summer/2006, the oils extracted by steam distillation and further analyzed by GC-MS. A total of 30 and 31 compounds was identified from the oils of $O$. selloi and $O$. canum, respectively. It was observed that the oil content of $O$. canum showed variation during the seasons, while the oils of $O$. selloi did not. Methylchavicol and linalool were the main chemical components found in the aerial parts and leaves of $O$. canum. This finding permitted to characterize this specimen as a new chemotype of $O$. canum. Regarding the aerial parts of $O$. selloi, eugenol, 1,8-cineole, transcaryophyllene and linalool were identified as their major components. All extracted oils from the aerial parts showed biological activity against gram-positive cocci - Staphylococcus aureus ATCC 25923 - but only the O. canum one showed activity against gram-negative bacilli - Escherichia coli ATCC 25922.
\end{abstract}

Key words: antimicrobial activity, essential oil, Lamiaceae, Ocimum canum, Ocimum selloi.

\section{INTRODUCTION}

The world trade for essential oils has been growing approximately $11 \%$ a year (Bizzo et al. 2009). In Brazil, the exports of essential oils have shown a significant increase in recent years, reaching U\$93,000,000 in 2008 (ALICE-Web System 2009). Among the species producing essential oils, those of the genus Ocimum have a small, but important contribution on the total exports.

The genus Ocimum L. (Lamiaceae) comprises about 160 species distributed in tropical and subtropi-

Correspondence to: Jeferson C. Nascimento

E-mail: jefersonchag@gmail.com

${ }^{1}$ It is a folk name. This "elixir" does not contain opium. cal Africa, Asia and South America (Gupta 1994), many of which are used in folk medicine, as spices and also to control insects (Grayer et al. 1996). Moreover, there is an economic exploitation by large-scale extraction of essential oils. Ocimum selloi is popularly known as "elixir paregórico"1 in the states of Rio de Janeiro and Espírito Santo, and as "anis" or "alfavaquinha" in Minas Gerais. These popular terms are related to its pharmacological properties and also to its chemical similarity to other species of Ocimum.

The volatile oils of $O$. selloi present antidiarrheal, antispasmodic and anti-inflammatory activities confirmed in preclinical testing (Vanderlinde et al. 1994). 
Besides, there are many other biological activities reported for the volatile oils produced by this genus, such as antimicrobial (Prasad et al. 1986, Nakamura et al. 1999, Farago et al. 2004, Bassole et al. 2005), insecticide (De Paula et al. 2003, Paula et al. 2004), antioxidant (Ganiyu 2008) and analgesic (Franca et al. 2008).

The essential oils of Ocimum are composed by compounds such as estragole, eugenol, methyleugenol, citral, linalool, geraniol and thymol. These compounds are required as raw materials for the pharmaceutical, comestics and food industries, and as insecticides (Craveiro and Queiroz 1993, Gupta 1994, Bizzo et al. 2009).

As a continuation of our studies on the composition of aromatic and medicinal plants cultivated in different parts of Brazil (Barbosa et al. 2005, Fonseca et al. 2006, Silva et al. 2007a), we describe in this paper the results of our investigation on the chemical composition and antimicrobial activities of the volatile oils produced by $O$. canum Sims and $O$. selloi Benth.

\section{MATERIALS AND METHODS}

\section{Plant Material}

The species were collected in August 2005 and January 2006 at 7:00 a.m. in the Garden of Medicinal Plants of the Universidade Estadual do Sudoeste da Bahia (UESB). Specimens were prepared, identified and deposited in the Herbarium of the Universidade Estadual de Santa Cruz (Ilhéus-BA, Brazil) under 4385 and 4387 numbers for $O$. canum and $O$. selloi, respectively.

\section{Extraction And Chemical Analyses of the} Volatile Oils

For each species, $100 \mathrm{~g}$ of fresh plant material from the aerial parts (leaves and fine stems) and from leaves, separately, were chopped and then subjected to a hydrodistillation in a Clevenger $(1.5 \mathrm{~h})$. The resulting oils were dried over anhydrous sodium sulphate (Merck), weighed and the reported yields calculated with respect to the fresh material weight. All distillations were repeated three times and the obtained oils were stored under nitrogen atmosphere and maintained at approximately $0^{\circ} \mathrm{C}$, until their analysis.

GC analyses were accomplished with a GC-17A Series instrument (Shimadzu, Japan) equipped with a flame ionization detector (FID). Chromatographic con- ditions were: fused silica capillary column $(30 \mathrm{~m} \times 0.22$ $\mathrm{mm})$ with a DB-5 bonded phase $(0.25 \mu \mathrm{m}$ film thickness); carrier gas, $\mathrm{N} 2$ at a flow rate of $1.8 \mathrm{~mL} / \mathrm{min}$; injector temperature $220^{\circ} \mathrm{C}$, detector temperature $240^{\circ} \mathrm{C}$; column temperature was programmed to start at $40^{\circ} \mathrm{C}$ (isothermal for $2 \mathrm{~min}$ ), with an increase of $3^{\circ} \mathrm{C} / \mathrm{min}$, to $240^{\circ} \mathrm{C}$, isothermal at $240^{\circ} \mathrm{C}$ for 15 minutes; injection of $1.0 \mu \mathrm{L}\left(1 \% \mathrm{w} / \mathrm{v}\right.$ in $\left.\mathrm{CH}_{2} \mathrm{Cl}_{2}\right)$; split ratio $1: 10$; column pressure of $115 \mathrm{kPa}$.

The compounds were identified using a GC-MS unit (model GCMS-QP5050A, from Shimadzu, Japan) equipped with a DB- 5 fused silica column $(30 \mathrm{~m} \times 0.22$ $\mathrm{mm}$ i.d., film thickness $0.25 \mu \mathrm{m}$ ) and interfaced with an ion trap detector. Oven and injector temperatures were as described above; transfer line temperature, $240^{\circ} \mathrm{C}$; ion trap temp., $220^{\circ} \mathrm{C}$; carrier gas, $\mathrm{He}$ at a flow rate of $1.8 \mathrm{~mL} / \mathrm{min}$; split ratio $1: 10$; column pressure of $100 \mathrm{kPa}$; ionization energy, $70 \mathrm{eV}$; scan range, 29-450 u; scan time, $1 \mathrm{~s}$. The components were characterized by the comparison of their retention indexes (RI) relative to a standard alkane series $\left(\mathrm{C}_{9}-\mathrm{C}_{24}\right)$, and also by the comparison of their mass spectrum with reference data from either the equipment database (Wiley 7 library) or literature (Adams 1995).

\section{ANTIBACTERIAL ACTIVITY}

The antimicrobial activity tests on the oils were performed by the method of diffusion in agar previously described (Bauer et al. 1966, Casteels et al. 1993, Fontana et al. 2004). The oils were tested against grampositive and gram-negative species, Staphylococcus aureus (ATCC 25923) and Escherichia coli (ATCC 25922), respectively. A suspension of the tested microorganism ( 0.5 of MacFarland Scale) was spread on Petri plates with Mueller Hinton agar (Difco Laboratories). A $2 \mathrm{~mm}$ hole diameter was opened on the surface of inoculated plates to which were added $10 \mu \mathrm{L}$ of an essential oil. The plates were incubated at $37^{\circ} \mathrm{C}$ for 24 hours. After this period of time, the diameters of the inhibition zones were measured using a caliper rule and expressed in millimeters.

\section{RESULTS AND DISCUSSION}

The essential oils of aerial parts (leaves and stems) of $O$. canum and $O$. selloi collected in the summer yielded 
$0.12^{2} \pm 0.002 \%(\mathrm{w} / \mathrm{w})$ and $0.16 \pm 0.003 \%(\mathrm{w} / \mathrm{w})$ respectively, while the oils obtained from the winter specimens yielded $0.06 \pm 0.010 \%$ and $0.18 \pm 0.004 \%$, respectively. The leaves of $O$. canum, when submitted to extraction, yielded $0.16 \pm 0.003 \%$ of oil in the summer and $0.08 \pm 0.006 \%$ in the winter, and the ones of O. selloi $0.18 \pm 0.004 \%$ in the summer and $0.20 \pm$ $0.005 \%$ in the winter.

The yield of volatile oils extracted from the aerial parts and leaves of $O$. canum in the summer is doubled compared to the winter, in agreement with the results obtained for O. basilicum L. (Silva et al. 2005). These results suggest that the seasonality may be one of the factors that should be considered when dealing with a possible economic exploitation. Other possible factors related to this variation can be rainfall, climate and leaf development (Gobbo-Neto and Lopes 2007). For the content of the essential oil of $O$. selloi, a significant variation on the yielding values for leaves and aerial parts in the two samples was not observed. Similar results were previously described by Moraes et al. (2002). Thus, these findings can suggest that, for this species, the seasonality is not a factor that could influence in the amount of essential oils produced.

The chemical composition of the essential oils of the aerial parts and leaves obtained in the winter of 2005 and in the summer of 2006 for O. canum is formed by methylchavicol and linalool, respectively, as its major constituents (Table I, Figures 2, 3, 6 and 10). $O$. canum is known to present different chemotypes with the volatile oils constituted mainly of linalool and limonene (Ngassoum et al. 2004, Ravid et al. 1997), methylcinnamate and caryophyllene (Murillo and Viña 2003, Martins et al. 1999), fenchone (Lawrence et al. 1980), eugenol (Ekundayo et al. 1989), 1,8-cineole (Bassole et al. 2005), citral (Choudhary et al. 1989), terpinen-4-ol (Sanda et al. 1998) and camphor (Chagonda et al. 2000). Therefore, according to the present study, it can be suggested that the plant under investigation may constitute a new chemotype methylchavicol and linalool. However, proposing the existence of a new chemotype has to be taken carefully since the chemical composition of the volatile oils can vary with the sea-

\footnotetext{
$\overline{2 \text { Mean of three replications }} \pm \mathrm{SD}$.
}

son, plant origin, plant age and soil composition, among other factors (Castro et al. 2004, Martins et al. 2006, 2007, Barbosa et al. 2007, 2008). In the present investigation, the influence of the harvest season on the composition of volatile oils is also observed. Specifically in the case of linalool content, a significant increase in aerial parts was observed in the winter compared to the summer.

Eugenol, 1,8-cineole, trans-caryophyllene and linalool were found to be major chemical constituents of essential oils of aerial parts from $O$. selloi (Table II, Figures 1, 4, 5, 6, 7, 8 and 9) in the two seasons. Therefore, it suggests that the access of $O$. selloi belongs to the eugenol chemotype (Farago et al. 2004, Paula et al. 2004). There are other chemotypes reported for this plant, such as estragole and methyleugenol (Martins et al. 1997, De Paula et al. 2003, Franca et al. 2008), trans-anethole (Moraes et al. 2002) and elemicine (David et al. 2006). It is noteworthy that, despite the literature describes the existence of an eugenol chemotype, as far as we know there are no GC nor GC-MS analyses reported for this variety. The results reported in the present investigation show small differences in the eugenol, 1,8-cineole, trans-caryophyllene and linalool contents present within the volatile oils from the aerial parts extracted during the winter 2005 and the summer 2006. Chromatograms of essential oils of Ocimum selloi and $O$. canum analyzed by GC/MS and mass spectra of major compounds identified in these oils, with the Retention time (Rt) of these compounds in the respective oils are presented in the Figures 1-10.

The results presented above should be analyzed carefully because, as previously discussed, individuals of the same species may contain many different volatile compounds. These variations are related to environmental factors such as temperature, soil type, moisture, climate, height and factors intrinsic to the plant, as its pathological condition and age (Barbosa et al. 2007, Martins et al. 2006, Silva et al. 2007b). The content of metabolites may also vary depending on the extraction method used (Charles and Simon 1990, Silva et al. 2004).

The essential oil of the aerial parts of $O$. sello $i$ showed an $8 \mathrm{~mm}$ diameter of inhibition zone against 
TABLE I

Chemical constituents of essential oil of Ocimum canum Sims.

\begin{tabular}{|c|c|c|c|c|c|c|}
\hline \multirow{3}{*}{ Compound } & \multirow{3}{*}{$\begin{array}{c}\text { RI } \\
\text { Cal. }\end{array}$} & \multirow{3}{*}{$\begin{array}{l}\text { RI } \\
\text { Lit. }\end{array}$} & \multicolumn{4}{|c|}{ Percentage of area on } \\
\hline & & & \multicolumn{2}{|c|}{ Aerial parts } & \multicolumn{2}{|c|}{ Leaves } \\
\hline & & & August 2005 & February 2006 & August 2005 & February 2006 \\
\hline$\alpha$-pinene & 931 & 939 & $\operatorname{Tr}$ & $0.20 \pm 0.02$ & - & $\operatorname{tr}$ \\
\hline Camphene & 944 & 953 & $\operatorname{Tr}$ & $\operatorname{tr}$ & - & $\operatorname{tr}$ \\
\hline$\beta$-pinene & 972 & 980 & $\operatorname{Tr}$ & $0.32 \pm 0.07$ & $\operatorname{tr}$ & $\operatorname{tr}$ \\
\hline$\beta$-myrcene & 989 & 991 & $\operatorname{tr}$ & $0.18 \pm 0.05$ & $\operatorname{tr}$ & $\operatorname{tr}$ \\
\hline$\alpha$-terpinene & 1011 & 1018 & $\operatorname{tr}$ & $\operatorname{tr}$ & $\operatorname{tr}$ & $\operatorname{tr}$ \\
\hline 1,8-cineole & 1029 & 1033 & $3.47 * 4.39$ & $4.98 \pm 0.37$ & $2.45 \pm 0.61$ & $2.51 \pm 2.01$ \\
\hline$\gamma$-terpinene & 1056 & 1062 & $\operatorname{tr}$ & $0.21 \pm 0.04$ & $\operatorname{tr}$ & $0.11 \pm 0.03$ \\
\hline Fenchone & 1082 & 1087 & $\operatorname{tr}$ & $\operatorname{tr}$ & $\operatorname{tr}$ & $0.10 \pm 0.20$ \\
\hline Linalool & 1098 & 1098 & $\mathbf{3 3 . 0 7} \pm \mathbf{2 . 0 8}$ & $26.74 \pm 1.85$ & $30.81 \pm 2.45$ & $23.93 \pm 4.00$ \\
\hline Camphor & 1138 & 1143 & $0.19 \pm 0.05$ & $0.41 \pm 0.05$ & $0.19 \pm 0.08$ & $0.36 \pm 0.04$ \\
\hline Borneol & 1164 & 1165 & $0.20 \pm 0.01$ & $0.17 \pm 0.02$ & $0.18 \pm 0.04$ & $0.13 \pm 0.02$ \\
\hline trans- $\beta$-terpineol & 1163 & 1163 & $0.20 \pm 0.01$ & $0.17 \pm 0.02$ & $0.18 \pm 0.04$ & $0.13 \pm 0.02$ \\
\hline terpinen-4-ol & 1174 & 1177 & $1.56 \pm 0.01$ & $1.64 \pm 0.09$ & $1.53 \pm 0.18$ & $1.75 \pm 0.30$ \\
\hline$\alpha$-terpineol & 1189 & 1189 & $0.93 \pm 0.14$ & $0.78 \pm 0.13$ & $0.82 \pm 0.13$ & $0.88 \pm 0.22$ \\
\hline methylchavicol & 1195 & 1195 & $46.38 \pm 7.50$ & $\mathbf{5 2 . 7 1} \pm \mathbf{8 . 5 9}$ & $56.78 \pm 4.94$ & $63.34 \pm 5.35$ \\
\hline endo fenchyl acetate & 1215 & 1220 & $0.25 \pm 0.01$ & $0.21 \pm 0.03$ & $\operatorname{tr}$ & $0.19 \pm 0.05$ \\
\hline bornyl acetate & 1280 & 1285 & $0.99 \pm 0.05$ & $0.64 \pm 0.18$ & $0.54 \pm 0.14$ & $0.56 \pm 0.20$ \\
\hline Eugenol & 1356 & 1356 & $2.28 \pm 1.98$ & $2.60 \pm 2.04$ & $0.68 \pm 0.05$ & $0.23 \pm 0.10$ \\
\hline$\beta$-elemene & 1388 & 1391 & $0.35 \pm 0.13$ & $0.29 \pm 0.26$ & $\operatorname{tr}$ & $0.13 \pm 0.03$ \\
\hline trans-caryophylllene & 1414 & 1418 & $0.79 \pm 0.75$ & $0.50 \pm 0.38$ & $0.26 \pm 0.02$ & $0.12 \pm 0.01$ \\
\hline $\operatorname{trans}$ - $\alpha$-bergamotene & 1432 & 1436 & $2.86 \pm 0.37$ & $1.70 \pm 0.27$ & $1.77 \pm \mathbf{0 . 4 0}$ & $1.61 \pm 0.45$ \\
\hline$\alpha$-humulene & 1448 & 1454 & $\operatorname{tr}$ & $\operatorname{tr}$ & $\operatorname{tr}$ & $\operatorname{tr}$ \\
\hline germacrene D & 1474 & 1480 & $0.90 \pm 0.09$ & $0.52 \pm 0.14$ & $0.44 \pm 0.18$ & $0.44 \pm 0.14$ \\
\hline bicyclogermacrene & 1491 & 1494 & $0.60 \pm 0.42$ & $0.60 \pm 0.42$ & $0.27 \pm 0.08$ & $0.18 \pm 0.05$ \\
\hline germacrene A & 1499 & 1503 & $0.51 \pm 0.33$ & $0.54 \pm 0.29$ & $0.25 \pm 0.12$ & $0.23 \pm 0.07$ \\
\hline$\gamma$-cadinene & 1507 & 1513 & $0.69 \pm 0.24$ & $0.38 \pm 0.10$ & $0.52 \pm 0.15$ & $0.44 \pm 0.15$ \\
\hline$\delta$-cadinene & 1516 & 1524 & $0.78 \pm 0.11$ & $\operatorname{tr}$ & - & $0.13 \pm 0.04$ \\
\hline germacrene B & 1550 & 1556 & $\operatorname{tr}$ & $\operatorname{tr}$ & $\operatorname{tr}$ & - \\
\hline Spathulenol & 1571 & 1576 & $\operatorname{tr}$ & $\operatorname{tr}$ & $\operatorname{tr}$ & - \\
\hline Cedrol & 1606 & 1596 & $0.35 \pm 0.06$ & $0.22 \pm 0.09$ & $0.27 \pm 0.13$ & $0.24 \pm 0.08$ \\
\hline Cadinol & 1635 & 1640 & $2.49^{\mathrm{a}} \pm 0.34$ & $1.18^{\mathrm{a}} \pm 0.53$ & $1.99 \pm 0.86$ & $1.59 \pm 0.56$ \\
\hline Total & & & 96.68 & 98.04 & 99.93 & 99.33 \\
\hline
\end{tabular}

*All values reported as an average of three replicates $\pm \mathrm{SD}$; $\mathrm{tr}$ - trace compound (less than $0.10 \%$ ); RI Cal.

- retention indices calculated; RI Lit. = Adams 1995.

Staphylococcus aureus, and it did not show inhibition against Escherichia coli. The oil of $O$. canum showed $9 \mathrm{~mm}$ of inhibition for both microorganisms. For the negative control it was not observe any inhibition halo. As stated, the oil of $O$. canum presented, by the method of agar diffusion capacity, a $9 \mathrm{~mm}$ inhibition zone and, thus, it may be considered active against $S$. aureus (ATCC 25923) and E. coli (ATCC 25922). These findings are consistent with those previously reported (Bassole et al. 2005, Janssen et al. 1989). It was also possible to observe that the oil of $O$. selloi showed antibacterial activity against $S$. aureus (ATCC 25923). 
TABLE II

Chemical constituents of the essential oil of Ocimum selloi Benth.

\begin{tabular}{|c|c|c|c|c|}
\hline \multirow{3}{*}{ Compound* } & \multirow{3}{*}{$\begin{array}{r}\mathrm{RI} \\
\mathrm{Cal} .\end{array}$} & \multirow{3}{*}{$\begin{array}{l}\text { RI } \\
\text { Lit. }\end{array}$} & \multirow{2}{*}{\multicolumn{2}{|c|}{$\frac{\text { Percentage of area on }}{\text { Aerial parts }}$}} \\
\hline & & & & \\
\hline & & & August 2005 & February 2006 \\
\hline$\alpha$-pinene & 931 & 939 & $0.25^{*} \pm 0.20$ & $0.26 \pm 0.20$ \\
\hline camphene & 944 & 953 & $\operatorname{tr}$ & $\operatorname{tr}$ \\
\hline sabinene & 970 & 976 & $0.25 \pm 0.13$ & $0.22 \pm 0.16$ \\
\hline$\beta$-pinene & 972 & 980 & $1.02 \pm 0.55$ & $1.01 \pm 0.50$ \\
\hline$\beta$-myrcene & 989 & 991 & $0.40 \pm 0.15$ & $0.34 \pm 0.20$ \\
\hline 1,8-cineole & 1029 & 1033 & $18.68 \pm 6.02$ & $21.02 \pm 8.61$ \\
\hline$(Z)$ - $\beta$-ocimene & 1039 & 1040 & $4.52 \pm 0.31$ & $4.00 \pm 2.08$ \\
\hline$(E)$ - $\beta$-ocimene & 1048 & 1050 & $0.34 \pm 0.04$ & $0.27 \pm 0.23$ \\
\hline linalool & 1098 & 1098 & $6.10 \pm 1.82$ & $6.83 \pm 0.15$ \\
\hline borneol & 1162 & 1165 & $0.40 \pm 0.08$ & $0.39 \pm 0.05$ \\
\hline trans- $\beta$-terpineol & 1163 & 1163 & $0.40 \pm 0.08$ & $0.39 \pm 0.05$ \\
\hline terpinen-4-ol & 1176 & 1177 & $\operatorname{tr}$ & $0.18 \pm 0.05$ \\
\hline$\alpha$-terpineol & 1189 & 1189 & $1.17 \pm 0.18$ & $1.28 \pm 0.25$ \\
\hline methylchavicol & 1193 & 1195 & $0.29 \pm 0.23$ & $2.12 \pm 1.48$ \\
\hline$\delta$-elemene & 1133 & 1139 & $\operatorname{tr}$ & $0.18 \pm 0.05$ \\
\hline eugenol & 1356 & 1356 & $38.95 \pm 2.82$ & $\mathbf{3 7 . 2 7} \pm \mathbf{5 . 3 7}$ \\
\hline$\beta$-elemene & 1388 & 1391 & $1.88 \pm 0.36$ & $1.89 \pm 0.75$ \\
\hline methyleugenol & 1401 & 1401 & $\operatorname{tr}$ & - \\
\hline trans-caryophyllene & 1414 & 1418 & $8.31 \pm 1.17$ & $7.00 \pm \mathbf{0 . 8 7}$ \\
\hline trans- $\alpha$-bergamotene & 1432 & 1436 & $\operatorname{tr}$ & $0.25 \pm 0.07$ \\
\hline$\alpha$-humulene & 1448 & 1454 & $1.67 \pm 0.16$ & $1.48 \pm 0.27$ \\
\hline alloaromadendrene & 1453 & 1461 & 一 & $0.39 \pm 0.15$ \\
\hline$(E)-\beta$-farnesene & 1454 & 1458 & $0.41 \pm 0.12$ & - \\
\hline germacrene D & 1475 & 1480 & $0.22 \pm 0.03$ & $0.28 \pm 0.17$ \\
\hline bicyclogermacrene & 1491 & 1494 & $4.25 \pm 0.65$ & $4.49 \pm 0.96$ \\
\hline germacrene $\mathrm{A}$ & 1499 & 1503 & $3.27 \pm 1.06$ & $3.15 \pm 0.58$ \\
\hline germacrene B & 1550 & 1556 & $3.70 \pm 3.00$ & $0.57 \pm 0.15$ \\
\hline spathulenol & 1571 & 1576 & $1.11 \pm 0.31$ & $0.73 \pm 0.63$ \\
\hline caryophyllene oxide & 1575 & 1581 & $0.57 \pm 0.21$ & $0.79 \pm 0.55$ \\
\hline isospathulenol & 1632 & - & $0.21 \pm 0.02$ & - \\
\hline$\beta$-eudesmol & 1644 & 1649 & $\operatorname{tr}$ & - \\
\hline Total & & & 98.37 & 96.79 \\
\hline
\end{tabular}

*All values reported as an average of three replicates $\pm \mathrm{SD}$; $\operatorname{tr}$ - trace compound (less than 0.10\%); RI Cal. - retention indices calculated; RI Lit. = Adams 1995.

However, it did not show activity against E. coli (ATCC 25922). These results are in agreement with that previously observed (Farago et al. 2004), which reported a small antimicrobial activity of the essential oils of eugenol variety for both microorganims. The observed activity against $S$. aureus can be attributed to the large amount of eugenol present in the oil, as reported by Nakamura et al. (1999).

\section{ACKNOWLEDGMENTS}

We are grateful to Universidade Estadual do Sudoeste da Bahia (UESB) for a graduate scholarship (R.S. França), and for the financial support of this project. We also acknowledge to the Conselho Nacional de Desenvolvimento Científico e Tecnológico (CNPq) for research fellowships (JMD and LCAB) and financial support. 

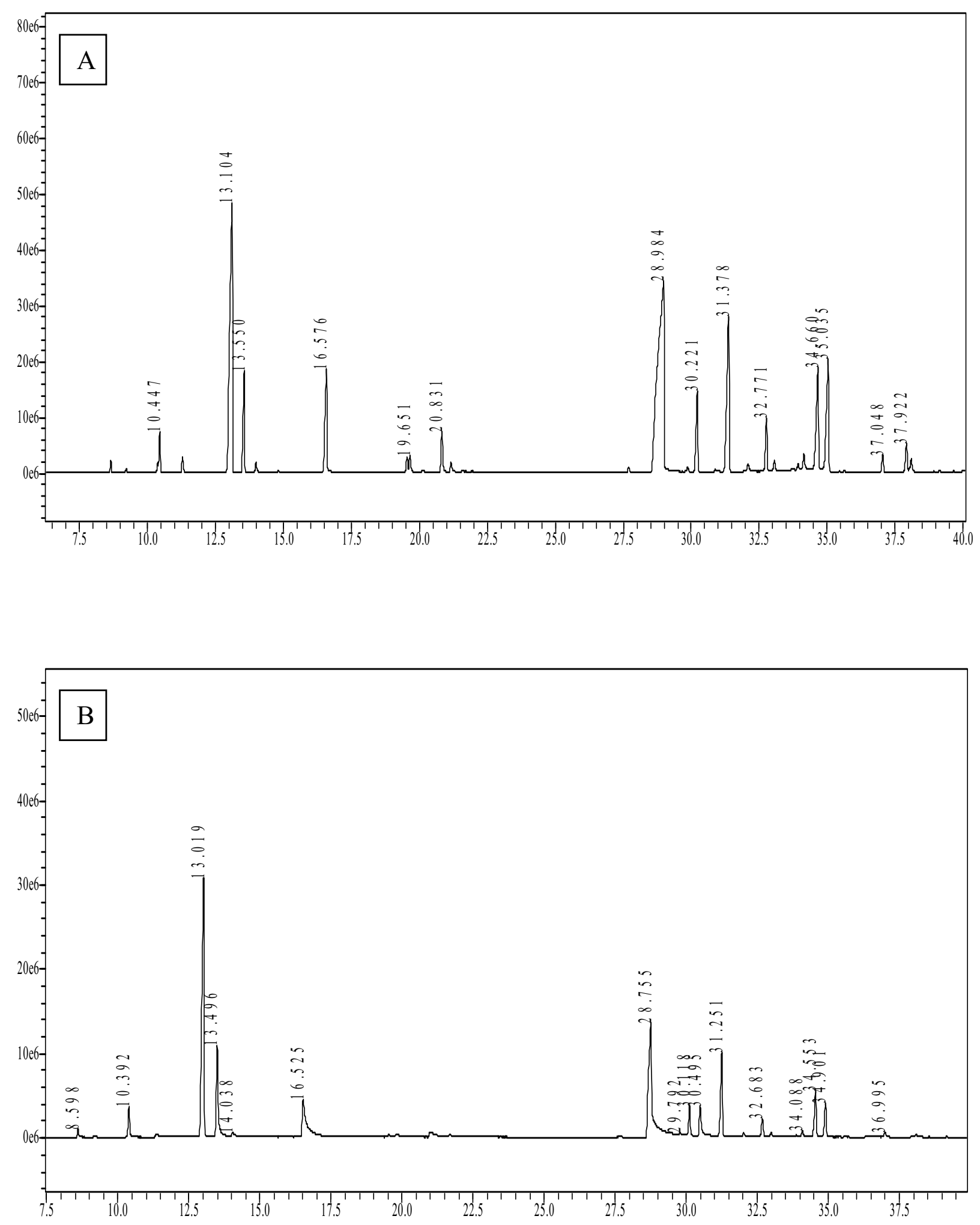

Fig. 1 - Chromatograms of essential oils of the aerial parts from Ocimum selloi (APOS) collected in the (A) winter (August/2005) and (B) summer (February/2006). 

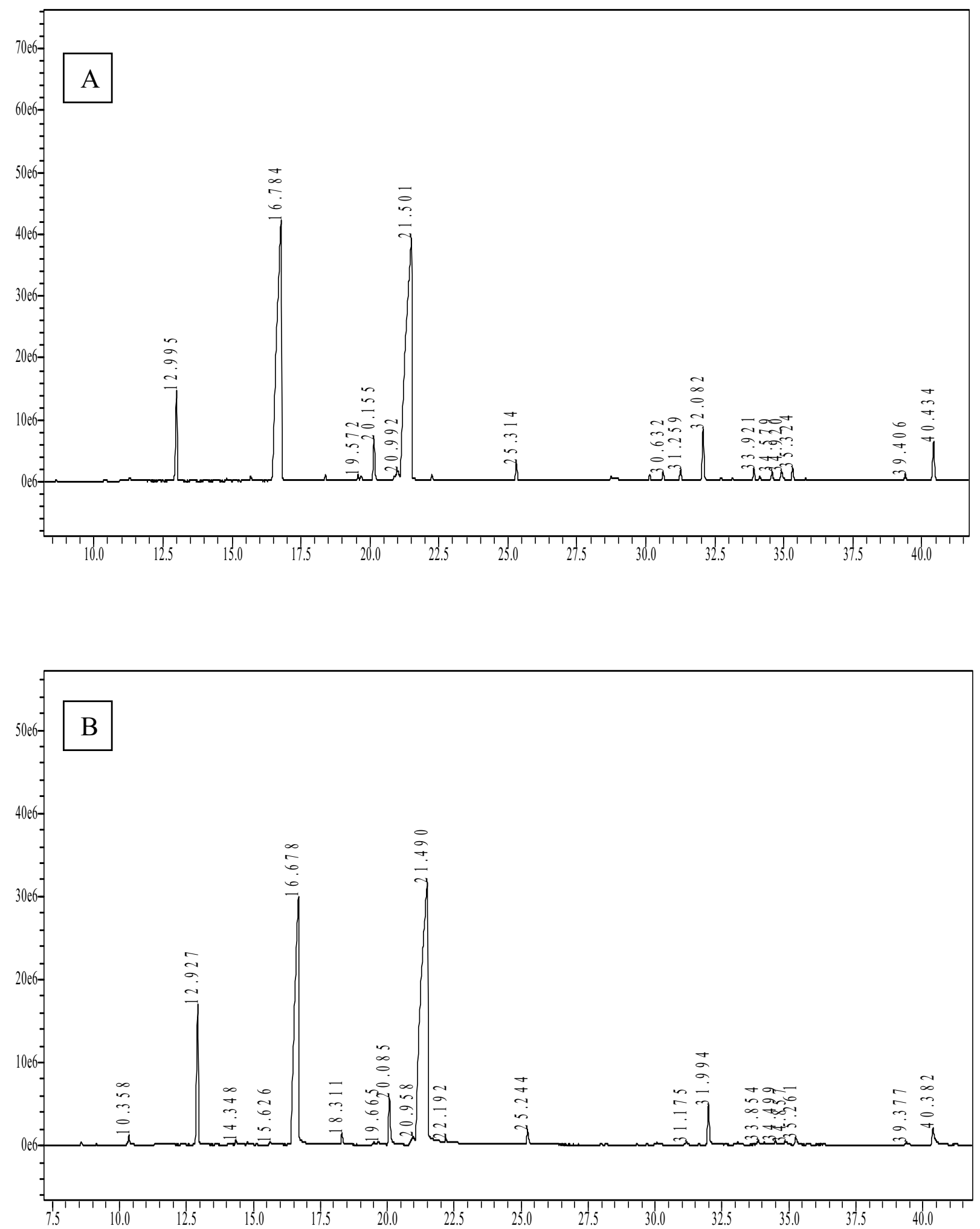

Fig. 2 - Chromatograms of essential oils of leaves from Ocimum canum (LOC) collected in the (A) winter (August/2005) and (B) summer (February/2006). 

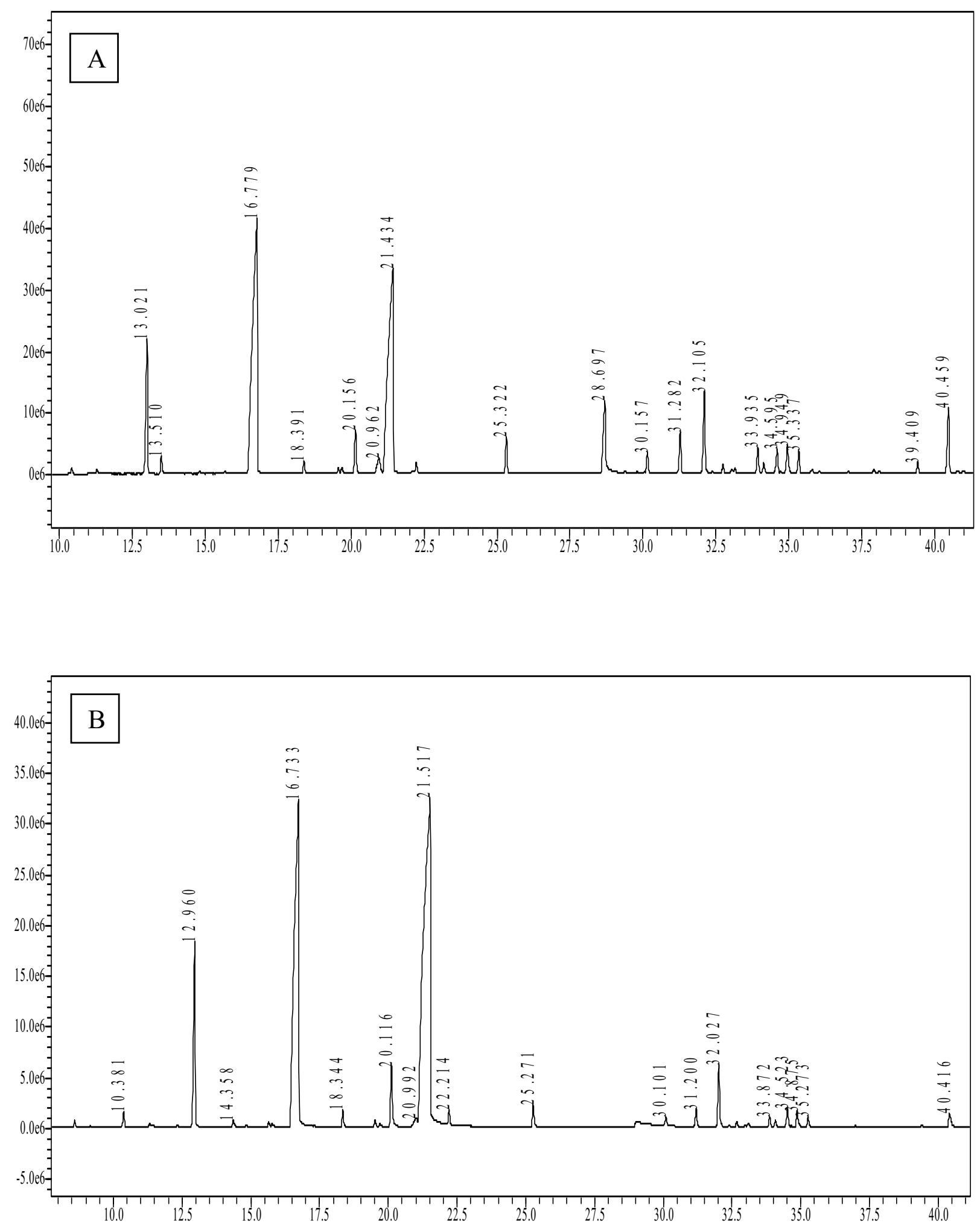

Fig. 3 - Chromatograms of essential oils of the aerial parts from Ocimum canum (APOC) collected in the (A) winter (August/2005) and (B) summer (February/2006). 


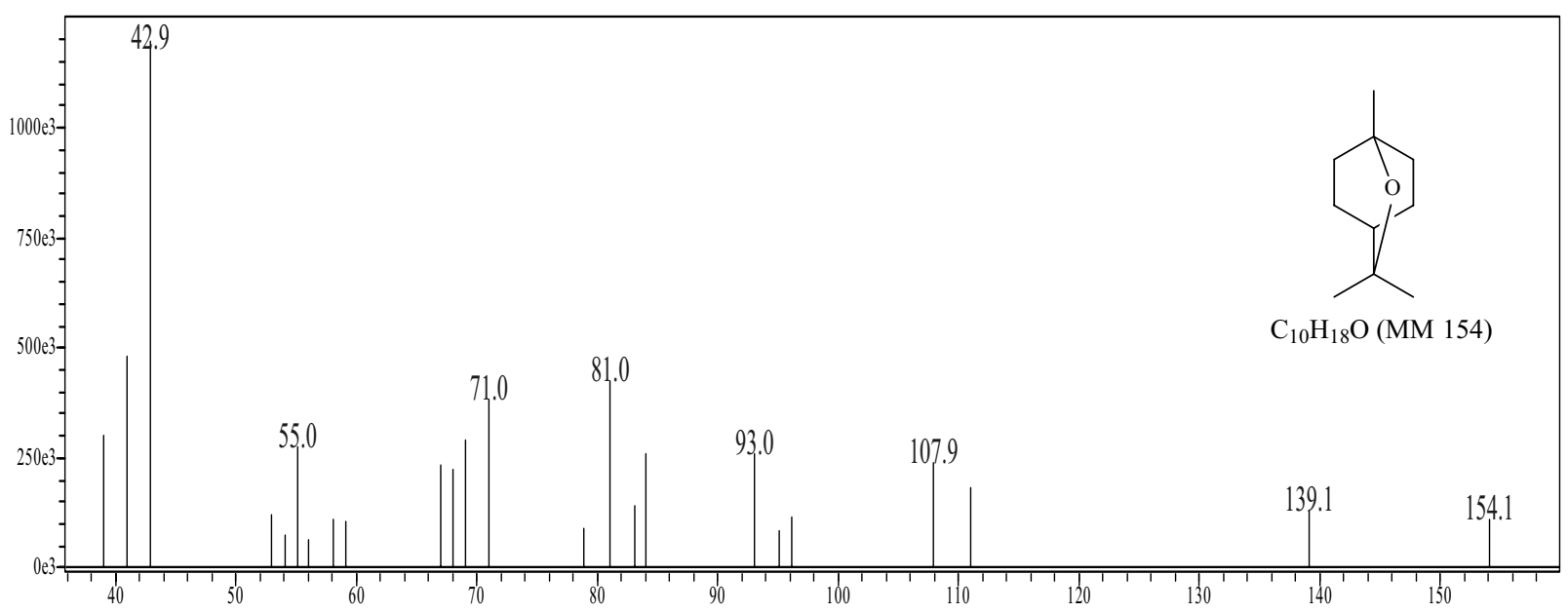

Fig. 4 - Mass spectrum of 1,8-cineole ( $\mathrm{Rt}=13.10,12.93$ and $12.96 \mathrm{~min}$, in APOS, LOC and APOC, respectively).

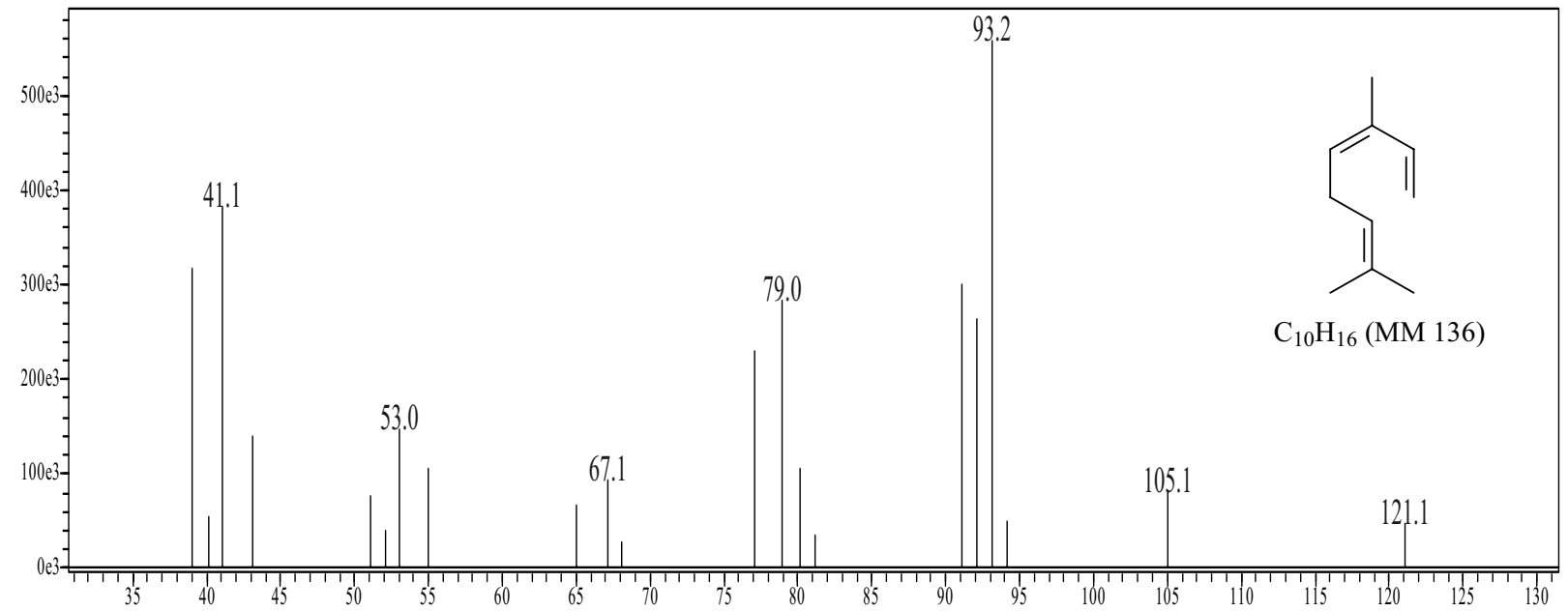

Fig. 5 - Mass spectrum of $(Z)-\beta$-ocimene $(\mathrm{Rt}=13.55 \mathrm{~min}$, in APOS).

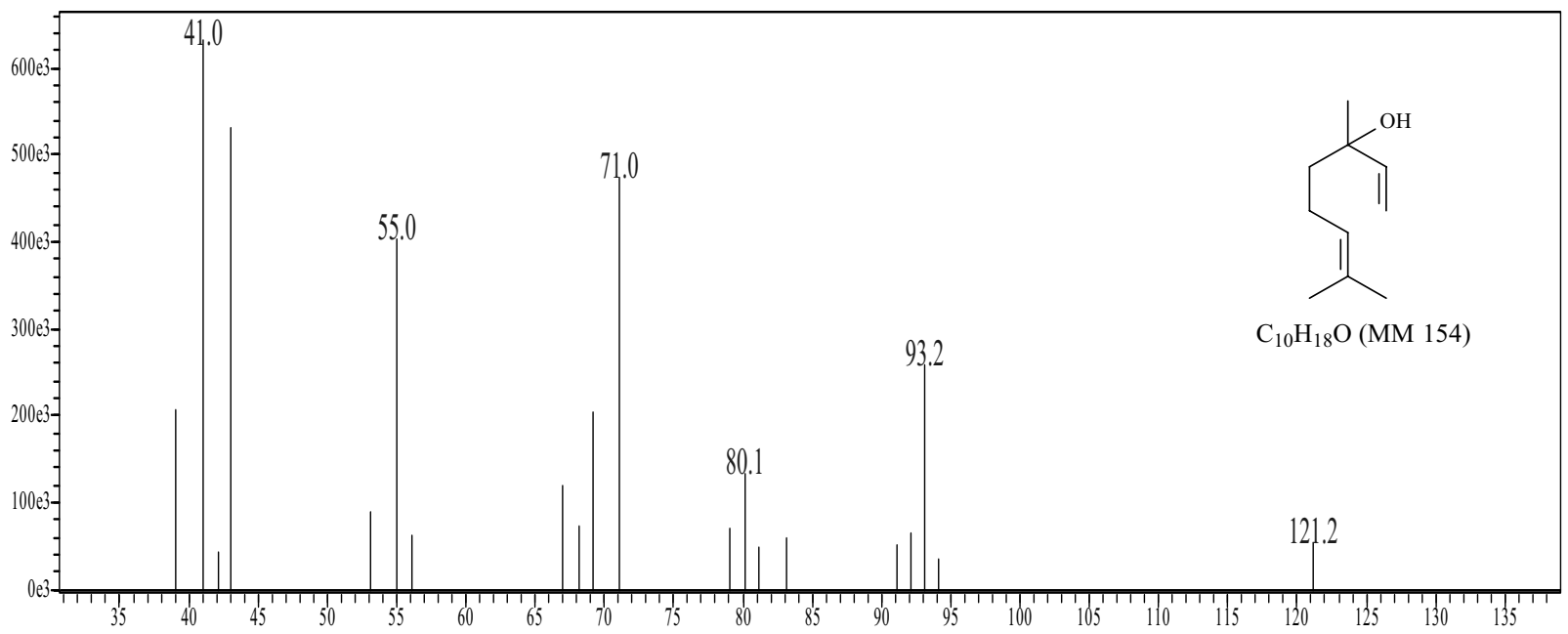

Fig. 6 - Mass spectrum of linalool ( $\mathrm{Rt}=16.57,16.78$ and $16.73 \mathrm{~min}$, in APOS, LOC and APOC, respectively). 


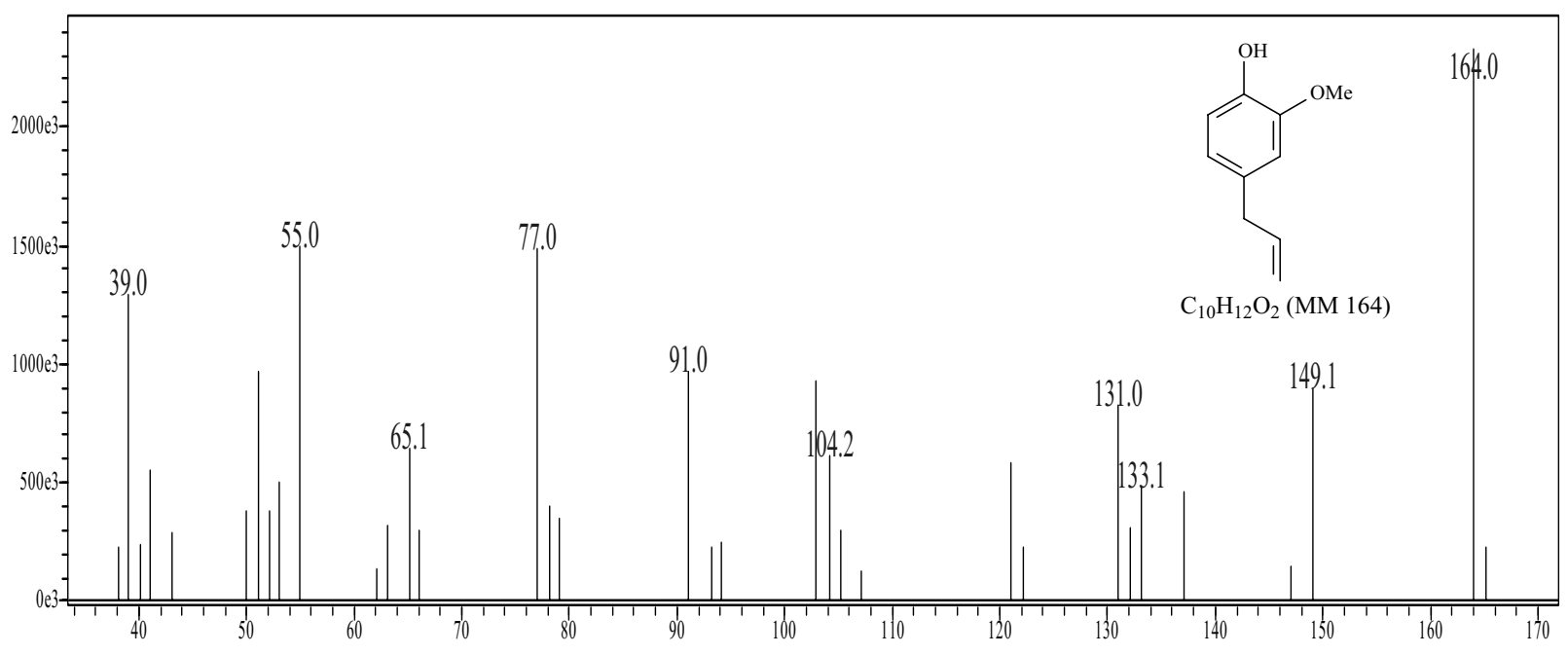

Fig. 7 - Mass spectrum of eugenol $(\mathrm{Rt}=28.98 \mathrm{~min}$, in APOS).

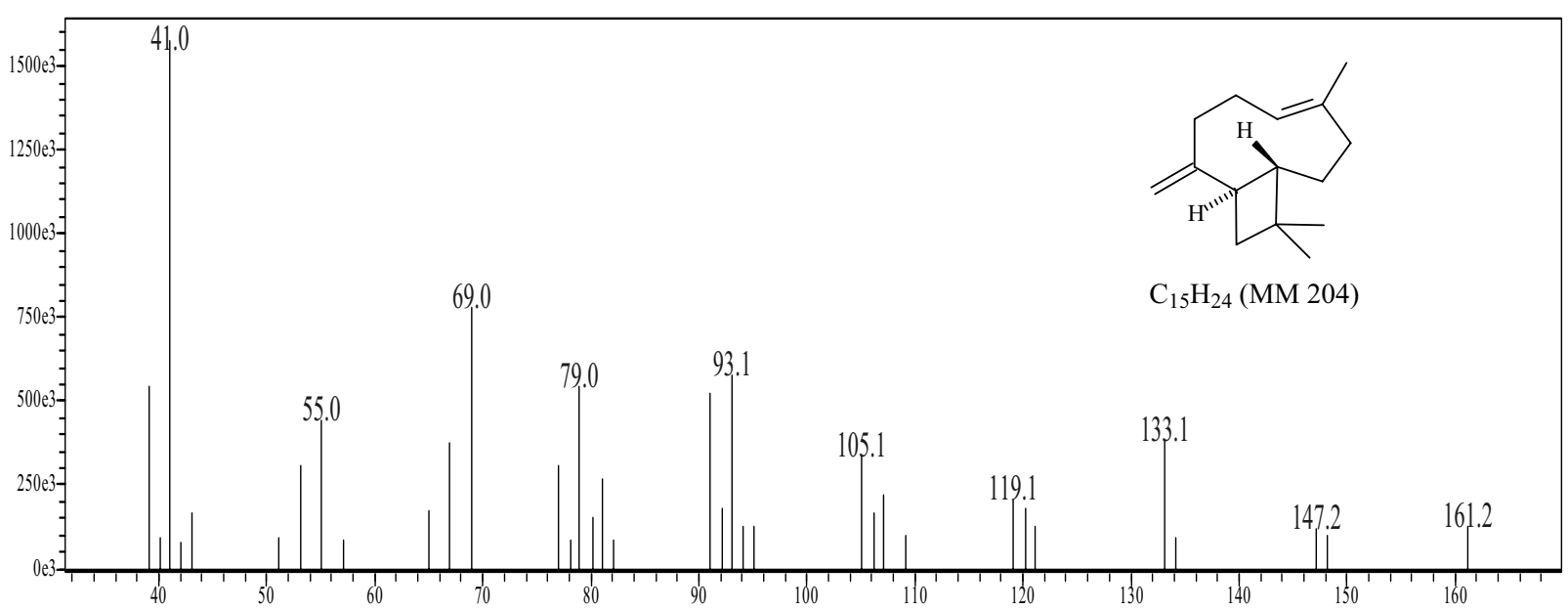

Fig. 8 - Mass spectrum of trans-caryophyllene $(\mathrm{Rt}=31.37 \mathrm{~min}$, in APOS).

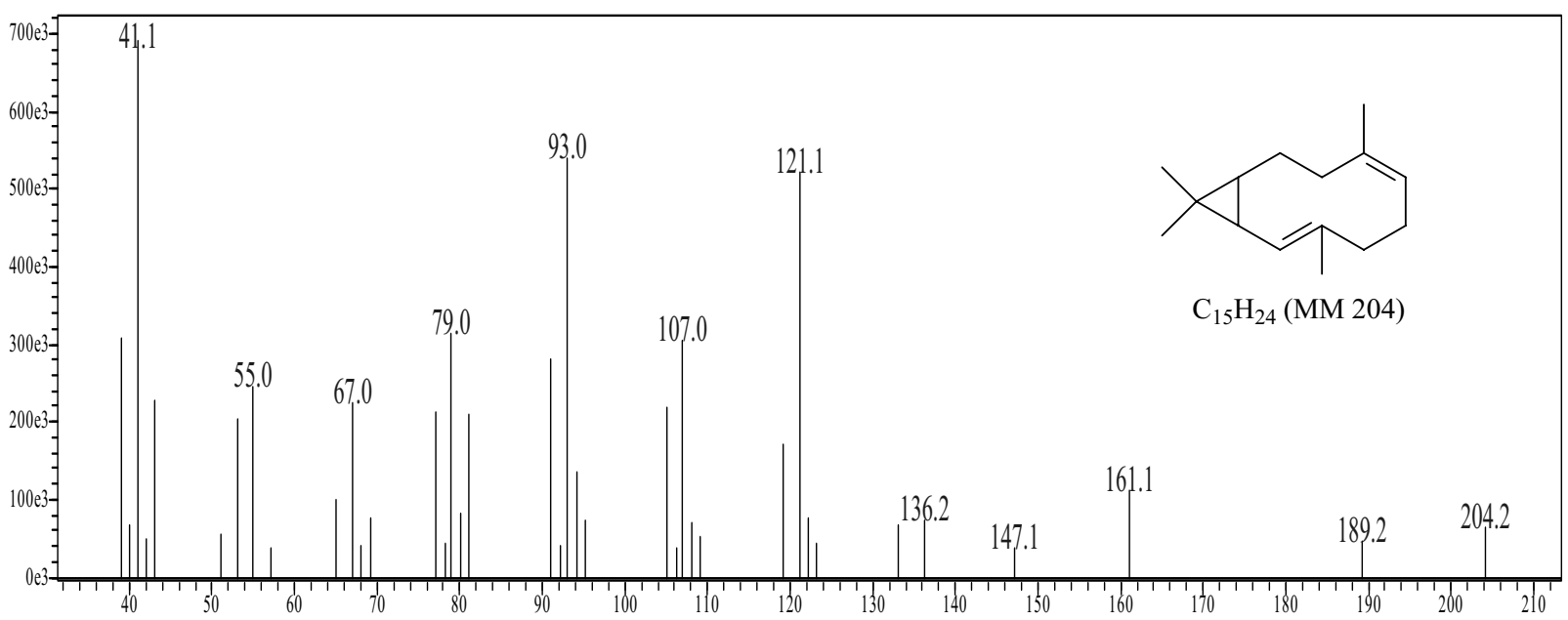

Fig. 9 - Mass spectrum of bicyclogermacrene $(\mathrm{Rt}=34.66 \mathrm{~min}$, in APOS). 


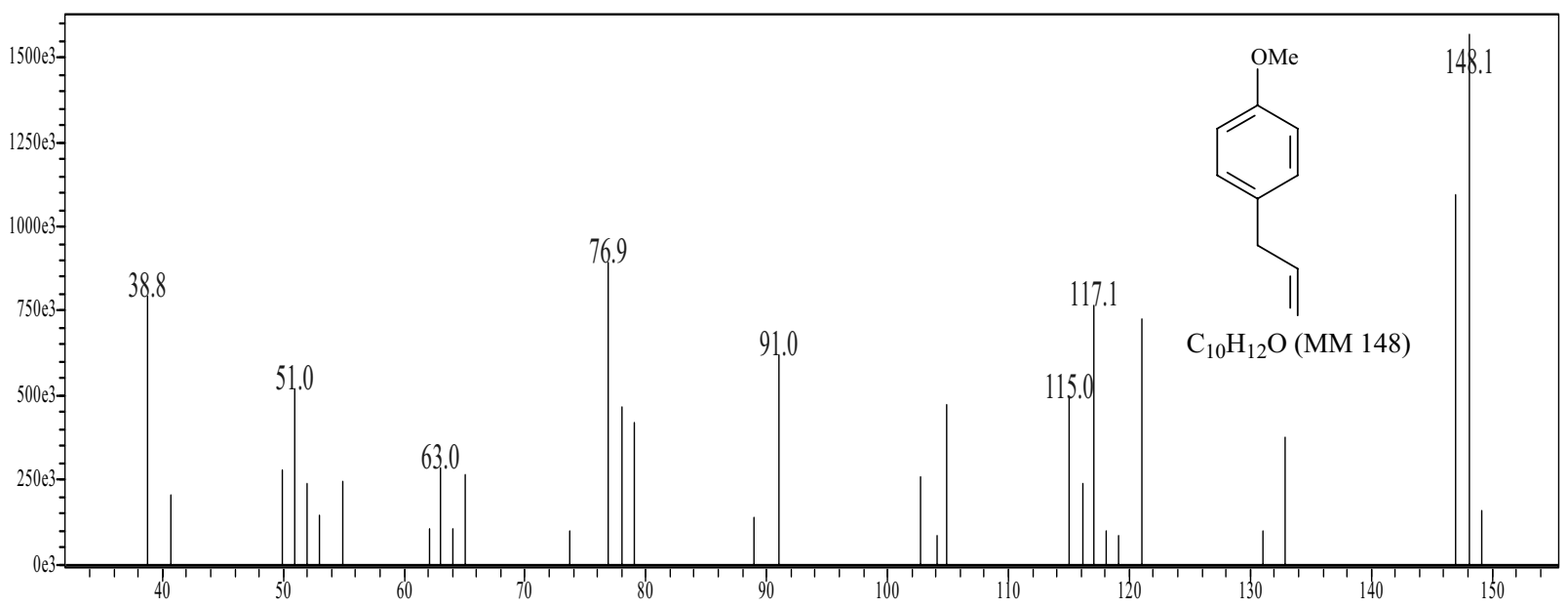

Fig. 10 - Mass spectrum of Methylchavicol ( $\mathrm{Rt}=21.50$ and $21.52 \mathrm{~min}$, in LOC and APOC, respectively).

\section{RESUMO}

Este trabalho descreve a composição química e a atividade antimicrobiana dos óleos voláteis de Ocimum canum e Ocimum selloi, que ocorrem em Jequié/BA, nordeste do Brasil. As plantas foram colhidas no inverno de 2005 e verão de 2006 e os óleos extraídos por destilação a vapor foram posteriormente analisados por GC-MS. Um total de 30 e 31 compostos foi identificado a partir dos óleos de O. selloi e $O$. canum, respectivamente. Foi observado que o teor de óleo de O. canum apresentou variação durante as estações do ano, enquanto o óleo de $O$. selloi não. Metilchavicol e linalol foram os principais componentes químicos encontrados na parte aérea e folhas de O. canum. Esta descoberta permitiu caracterizar este espécime como um novo quimiotipo de $O$. canum. Com relação às partes aéreas de $O$. selloi, eugenol, 1,8-cineol, transcariofileno e linalol foram identificadas como os seus principais componentes. Todos os óleos extraídos das partes aéreas apresentaram atividade biológica contra cocos gram-positivo - Staphylococcus aureus ATCC 25923 - mas apenas aquele de $O$. canum apresentou atividade contra bacilo gram-negativo - Escherichia coli ATCC 25922.

Palavras-chave: atividade antimicrobiana, óleo essencial, Lamiaceae, Ocimum canum, Ocimum selloi.

\section{REFERENCES}

ADAMS RP. 1995. Identification of essential oil components by gas chromatography mass spectroscopy Carol stream, Illinois, USA, 469 p.
Barbosa lCA, Demuner AJ, Clemente AD, Paula VF AND ISMAIL FMD. 2007. Seasonal variation in the composition of volatile oils from Schinus terebintifolius RADDI. Quim Nova 30: 1959-1965.

Barbosa lCA, Paula VF, Azevedo As, Silva EAM And NAscimento EA. 2005. Essential oil composition from some plant parts from Conyza bonariensis (L.) Cronquist. Flav Frag J 20: 39-41.

Barbosa lCA, Pereira UA, Martinazzo AP, Maltha CRA, Teixeira RR And Melo EC. 2008. Evaluation of the chemical composition of Brazilian commercial Evaluation of the chemical composition of Brazilian commercial Cymbopogon citrates (D.C.) Stapf samples. Molecules 13: 1864-1874.

Bassole IHn, Nebie R, Savadogo A, Ouattara CT, Barro N AND Traore SA. 2005. Composition and antimicrobial activities of the leaf and flower essential oils of Lippia chevalieri and Ocimum canum from Burkina Faso. Afric J Biotech 4: 1156-1160.

Bauer AW, Kerby WMM, Sherris JC ANd Turck N. 1966. Antibiotic susceptibility testing by a standardized single disc method. Amer J Clin Path 45: 493-496.

Bizzo HR, Hovell AMC And Rezende CM. 2009. Óleos essenciais no Brasil: Aspectos gerais, desenvolvimento e perspectivas. Quim Nova 32: 588-594.

Casteels P, Ampe C, Jacobs F And Tempst P. 1993. Functional and chemical characterizations of Hymenoptaecin, an antibacterial polypeptide that is infectioninducible in the Honeybee (Apis mellifera). J Biol Chem 268: 7044-7054. 
Castro hG, Oliveira lo, Barbosa lCA, Ferreira FA, Silva DJH, Mosquim PR AND NASCIMENTo EA. 2004. Content and composition of the essential oil of Five accesses of mentrasto. Quim Nova 27: 55-57.

Chagonda LS, Makanda CD and Chalchat JCC. 2000. The essential oils of Ocimum canum Sims. (basilicum camphor) and Ocimum urticifolia Roth from Zimbabwe. Flav Frag J 15: 23-26.

Charles DJ AND Simon JE. 1990. Comparison of extraction methods for the rapid determination of essential oil content and composition of basil. J Amer Soc Hort Sci 115: 458-462.

Choudhary R, Kharya MD, Dixit VK and Varma KC. 1989. Role of phytohormone on the cultivar and essential oil of Ocimum canum Sims. A potential source of citral. Indian Perfum 33: 224-227.

Craveiro AA AND QueIroz DC. 1993. Óleos essenciais e Química fina. Quim Nova 16: 224-228.

David EFS, Pizzolato M, Facanali R, Morais LAS, Ferri AF, Marques MOM AND Ming LC. 2006. Influencia da temperatura de secagem no rendimento e composição química do óleo essencial de Ocimum selloi Benth. Rev Bras P1 Medic 8: 66-70.

De Paula JP, Carneiro MRG and Paumgartten FJR. 2003. Chemical composition, toxicity and mosquito repellency of Ocimum selloi oil. J Ethnopharmac 88: 253-260.

EkUndayo O, LaAkso I and Hiltunen R. 1989. Constituents of the volatile oil from leaves of Ocimum canum Sims. Flav Frag J 4: 17-18.

FARAGo PV, PAUla JP, BitTEnCOURT JM, ZARPELLON V AND CHECCHIA LEM. 2004. Atividade antimicrobiana de óleos essenciais de Ocimum selloi Benth. Publ UEPG Ci Biol Saúde 10: 59-63.

Fonseca MCM, BARbosa LCA, NASCIMENTo EA AND CAsali VWD. 2006. Essential oil from the leaves and flowers for Porophyllum ruderale (Jacq.) Cassini (Asteraceae). 2006 J Essent Oil Res 18: 345-347.

Fontana R, Mendes MA, Souza BM, Donno K, CÉSAR LMM AND PALMA MS. 2004. Jelleines: a family of antimicrobial peptides from the royal jelly of honeybees (Apis mellifera). Peptides 27: 2624-2631.

Franca CS, Menezes FS, Costa LCB, Niculau ES, Alves PB, Pinto JEB And Marçal RM. 2008. Analgesic and antidiarrheal properties of Ocimum selloi essential oil in mice. Fitoterapia 79: 569-573.
GANIYU O. 2008. Antioxidative potential of Ocimum gratissimum and Ocimum canum leaf polyphenols and protective effects on some pro-oxidants induced lipid peroxidation in rat brain: an in vitro study. Amer J Food Technol 3: 325-334.

Gobbo-Neto L AND Lopes NP. 2007. Plantas medicinais: Fatores que influenciam no conteúdo de metabólitos secundários. Quim Nova 30: 374-381.

Grayer RJ, Kite GC, Golsdstone FJ, Bryan Paton A AND PUTLEVSKY E. 1996. Intraspecific taxonomy and essential oil chemotypes in sweet basil, Ocimum basilicum. Phytochemistry 4: 1033-1039.

GuPTA R. 1994. Basil (Ocimum spp.). G-15 Gene Banks for Medicinal and Aromatic Plants. Newsletter 1: 1-3.

JANSSEN AM, SChEFFER JJC, NTEZURUbANZA L AND BAERHEIM SA. 1989. Antimicrobial activities of some Ocimum species grown in Rwanda. J Ethnopharmac 26: 57-63.

LAwrence BM, Powel RH And Peele DM. 1980. Variation in the genus Ocimum. Proceeding of the eighth International Congress on Essential Oil, FEDAROM, Grasse, France, p. 109-117.

Martins AP, Salgueiro L, Vila R, Tomi F, CanigueRal S, Casanova J, Cunha AP And Adzet T. 1999. Composition of the essential oil of Ocimim canum. O. gratissimum, and O. minimum. Plant Med 65: $187-189$.

Martins ER, CASAli VWD, BARbosa LCA AND CARAzZA F. 1997. Essential oil in the taxonomy of Ocimum selloi Benth. J Braz Chem Soc 8: 29-32.

Martins FT, SAntos MH, Polo M AND Barbosa LCA. 2006. Chemical variation in the essential oil of Hyptis suaveolens (L.) Poit under cultivation condition. Quim Nova 29: 1203-1209.

Martins FT, SAntos MH, Polo M And Barbosa LCA. 2007. Effect of the interactions among macronutrients, plant age and photoperiod in the composition of Hyptis suaveolens (L.) Poit essential oil from Alfenas (MG), Brazil. Flav Frag J 22: 123-129.

Moraes ASL, Facanali R, Marques MOM, Ming CL AND MeIReles AMA. 2002. Phytochemical characterization of essential oil from Ocimum selloi. An Acad Bras Cienc 74: 183-186.

Murillo E AND ViÑA A. 2003. Essential oil composition from twelve varieties of Basil (Ocimum spp) grown in Colômbia. J Braz Chem Soc 14: 744-749. 
NAKAmura CV, UEda-Nakamura T, Bando E, Melo AFN, Cortez DAG and Dias Filho BP. 1999. Antibacterial activity of Ocimum grantissimum L. essential oil. Mem Inst Oswaldo Cruz 94: 675-678.

Ngassoum MB, Ousmaila H, Nagamo LT, MaponMETSEM PM, JiRovetz L AND BuChBAuer G. 2004. Aroma compounds of essential oils of two varieties of the spice plant Ocimum canum Sims. from Northern Cameroon. J Food Compos and Anal 17: 197-204.

Paula JP, Farago PV, Checchia Lem, Hirose KM AND RiBAS JLC. 2004. Atividade repelente do óleo essencial de Ocimum selloi Benth. (variedade eugenol) contra o Anopheles braziliensis Chagas. Acta Farm Bonaerense 23: 376-378.

Prasad G, Kumar A, Singh AK, Bhattacharya AK, SINGH K AND SHARMA VD. 1986. Antimicrobial activity of essential oils of some Ocimum species and clove oil. Fitoterapia 57: 429-432.

Ravid U, Putievsky E, Katzir I And Lewinsohn E. 1997. Enantiomeric composition of linalool in the essential oil of Ocimum species in commercial basil oils. Flav Frag J 12: 293-296.

SAndA K, KobA K, NAmbo P And GASET A. 1998. Chemical investigation of Ocimum species growing in Togo. Flav Frag J 13: 226-232.

Silva CJ, Barbosa lCA, Maltha CRA, Pinheiro AL AND ISMAIL FMD. 2007a. Comparative study of the essential oils of seven Melaleuca (Myrtaceae) species grown in Brazil. Flav Frag J 22: 474-478.
Silva F, SANTOS RHS, ANDRAde NJ, BARBosa LCA, CASAli VWD, LIMA RR AND PASSARINHO RVM. 2005. Basil conservation afected by cropping season, harvest time and storage period. Pesq Agropec Bras 40: 323-328.

Silva L, Carreira RC, Oniki GH, Agripino DG, YounG MCM AND LADEIRA AM. 2007b. Crescimento e análise do potencial antifúngico em plantas de Cissus verticillata (L.) Nicolson \& Jarvis (Vitaceae). Rev Bras P1 Medic 9: 73-79.

Silva MGV, Matos FJA, Lopes PRO, Silva FO AND HolAndA MT. 2004. Composition of essential oils from three Ocimum species obtained by steam and microwave distillation supercritical $\mathrm{CO}_{2}$ extraction. Arkivoc 6: 66-71.

VAnderlinde FA, Costa EA ANd D'Angelo LCA. 1994. Atividades farmacológicas gerais e atividade antiespasmódica do extrato etanólico de Ocimum selloi Benth. (elixir-paregórico). In: Simpósio de Plantas Medicinais do BRAsil, 13: Fortaleza: UFCE.

http://aliceweb.desenvolvimento.gov.br/, accessed 01 October 2009. 